\title{
An experiment in the prevention of meningococcal meningitis in Nigeria
}

\author{
R. L. VOLLUM AND P. W. W. GRIFFITHS \\ From the Department of Bacteriology, Radcliffe Infirmary, Oxford
}

SYNOPSIS In a population of approximately $100,000,99 \%$ of the population was treated with at? least one dose of sulphadimidine snuff and $94 \%$ with three or four doses over a period of two days. $\vec{~}$ A dramatic reduction in the incidence of cerebrospinal meningitis followed immediately thereafter-in the treated population, while the incidence continued to rise in adjacent comparable districtsO which had not been treated.

Epidemics of meningococcal meningitis recur periodically during the dry season in northern Nigeria and in other parts of Africa with a similar climate.

Horn (1951) has given an historical account of this disease in northern Nigeria, together with details of the 1949-50 epidemic. Conditions have not greatly changed since that time.

In Nigeria the most recent outbreaks have been in 1960 and 1961. Katsina, a province of northern Nigeria, has a population of about $1 \frac{1}{2}$ millions. In the 1960 epidemic there were 2,779 cases of meningitis with 263 deaths and in 1961, 6,668 cases with 508 deaths. Although the 1960 outbreak virtually ceased at the onset of the rains in June, 103 sporadic cases occurred during the six months between the epidemics and there were eight deaths. Thus between February 1960 and May 1961 there have been 9,550 cases of cerebrospinal meningitis with 779 deaths in a population of $1 \frac{1}{2}$ millions.

The authorities are well aware of the menace of this infection, and do their utmost in primitive conditions with inadequate medical and nursing staff to treat the victims and to prevent spread of the disease. Temporary isolation huts are set up outside village areas. These are simple huts made of matting with thatched roofs. There is, of course, no sanitary convenience, no water supply, and no electricity in these huts. A small fire in a gourd provides some heat when the temperature drops at night. The patient is usually accompanied by some member of the family who acts as a nurse. The district medical officer visits the villages and gives advice about treatment, but in a large district his

Received for publication 5 September 1961. visits are infrequent. Sulphadimidine treatment is given by the local dispensary attendant, or if there is no dispensary in the village, this duty falls to the ${ }^{₹}$ school master or some other official.

The meningococcus causes primarily a nasal $\stackrel{\circ}{\sim}$ infection, and meningitis may be considered as ac complication of an otherwise mild infection, which? will occur in a variable proportion of the carriers. In European communities, the general experiencen is that an epidemic of cerebrospinal meningitis mayळ occur when the carrier rate rises to 60 to $80 \%$.

A method of prophylaxis based on the elimination? of the carrier state by the use of a sulphonamide snuff was successfully carried out during some minor outbreaks of cerebrospinal meningitis near Oxford 20 years ago. It seemed probable that as similar method of prophylaxis might be applicableo in Nigeria. After discussion with the Emir of Katsina and his Council a plan was devised wherebyo virtually the whole population of a large district coulde be treated prophylactically with sulphadimidine? snuff simultaneously over a period of two days. The Ministry of Health at Kaduna supplied the sulo phadimidine. The Commonwealth Relations Office supported the scheme financially. The enthusiastic cooperation of the Emir of Katsina, with his staff made the whole venture possible.

Bacteriological facilities for detecting the carriers were very limited. A rather primitive laborator 6 was set up in a spare room at the hospital in Katsinac Nasal swabs were taken from various samplẹp groups of the population but it was not practicable to swab the whole population to detect the indiē vidual carriers. Nasal swabs were examined frong approximately 500 individuals in various come munities, and the carrier rate varied from 0 to $30 \%$ 
with an average of about $7 \%$. This result is comparable with the results reported by Horn (1951) who found in a previous epidemic that the carrier rate fluctuated around $20 \%$. If better laboratory facilities had been available, it is probable that a higher carrier rate would have been detected.

Unfortunately, due to administrative difficulties it was impossible to start prophylactic treatment before the incidence of meningitis in 1961 had reached epidemic proportions. The authorities then advised that, as the district of Danja was suffering more heavily than the rest of the area, and as the mortality rate was highest there, it would be the most appropriate place to carry out the investigation.

Danja district is a long, narrow district lying across the southern part of Katsina Province. It is ruled by a district head, the Makama of Danja, who is responsible to the Emir of Katsina. It is divided into 19 village areas, each of which has a village head. The village areas are subdivided into 131 hamlets.

The staff available for distributing sulphadimidine snuff consisted of the scribes, teachers, forestry assistants, a few dispensary attendants, and such other literate persons as could be found. A fortnight before the snuff was given, a meeting of the 190 staff was held at Bakori, when the procedure was explained in detail, and the technique of administering the snuff demonstrated.

The staff made a house-to-house census in the hamlet to which each was appointed. Forms were prepared to record the name, age, sex, and address of each individual, and the doses of sulphadimidine when given.

A major problem was undoubtedly that of strangers. Although the Hausas of northern Nigeria are a settled people, living in towns and villages, they are great travellers and will go 50 miles or more to markets, travelling on foot or riding donkeys. In addition there is a definite minority of nomadic pastoral people, the Fulani, who traverse the country with large herds of cattle. These people normally live in small temporary encampments but they enter the Hausa towns and villages quite freely in search of water and to attend the markets. Thus at the time when the villages were given the snuff, they, and particularly the market towns, contained unknown but probably considerable numbers of strangers. Naturally these had not been listed beforehand and although we tried at each centre to urge the importance of treating strangers and visitors, it was clear that most were not in fact treated.

Instructions were to give four doses to each individual, one dose in the morning and one in the evening on two successive days. Adults were able to take this snuff in the normal way. For young children, it was intended to use insufflators, but these unfortunately were not available. Various makeshift methods were used. In some cases a plastic talcum powder container proved to be a successful substitute.

The doses were administered personally by the appointed officer in each hamlet. In a few cases the appropriate amounts were given to husbands for their women in purdah. This arrangement is unsatisfactory as there is no guarantee that the doses are properly given, and failure of the husband to attend at the centre would result in failure of his women to get their proper dosage.

The population as a whole was enthusiastic and flocked to the centres. Unfortunately in some places there was congestion and overcrowding due to delays caused by the elaborate method of identification of individuals and the detailed records kept. The officials in charge had no previous experience and their task was not entirely easy.

In spite of difficulties, the administration of the snuff was very successful. Of the total recorded population of $99,986,87 \%$ received four doses and a further $7 \%$ received three doses, making a total of $94 \%$ who had three or four doses (Table I).

\section{TABLE I}

ADMINISTRATION OF SULPHADIMIDINE SNUFF IN DANJA DISTRICT

\begin{tabular}{lllllrr} 
Village Areas & $\begin{array}{l}\text { Recorded } \\
\text { Population }\end{array}$ & $\begin{array}{l}\text { Four } \\
\text { Doses }\end{array}$ & $\begin{array}{l}\text { Three } \\
\text { Doses }\end{array}$ & $\begin{array}{l}\text { Two } \\
\text { Doses }\end{array}$ & $\begin{array}{l}\text { One } \\
\text { Dose }\end{array}$ & $\begin{array}{l}\text { O } \\
\text { Dose }\end{array}$ \\
\hline Kandarawa & 5,417 & 5,083 & 287 & 38 & 6 & 3 \\
Jiba & 4,999 & 4,798 & 113 & 30 & 11 & 47 \\
Yakaji & 6,460 & 5,384 & 570 & 420 & 52 & 34 \\
Kabomo & 3,763 & 3,559 & 186 & 13 & 2 & 3 \\
Guga & 5,431 & 4,994 & 362 & 31 & 7 & 37 \\
Tsiga & 7,095 & 6,903 & 138 & 9 & 22 & 23 \\
D. Musa & 4,382 & 4,345 & 31 & 3 & 0 & 3 \\
Yankwani & 4,609 & 4,466 & 100 & 10 & 10 & 23 \\
Bakori & 7,104 & 5,772 & 587 & 519 & 119 & 107 \\
Barde & 3,755 & 3,618 & 52 & 4 & 3 & 78 \\
Tsangamawa & 5,778 & 4,415 & 850 & 271 & 120 & 122 \\
Dabai & 5,347 & 4,541 & 571 & 137 & 46 & 52 \\
Kwantadwaram & 2,729 & 2,254 & 253 & 110 & 43 & 69 \\
Jargaba & 3,976 & 3,497 & 299 & 76 & 36 & 68 \\
Danja & 7,878 & 5,718 & 1,297 & 590 & 186 & 87 \\
Tandama & 3,992 & 3,788 & 173 & 15 & 8 & 8 \\
Kuranu & 4,885 & 4,699 & 146 & 37 & 0 & 3 \\
Kahutu & 7,099 & 5,037 & 1,135 & 518 & 283 & 126 \\
Kakumi & 5,287 & 4,858 & 307 & 42 & 4 & 76
\end{tabular}

Total population, 99,986

Number receiving 4 doses $87,729(87 \%)\} 94 \%$

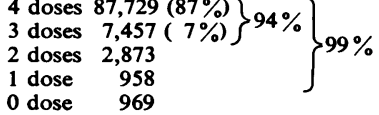




\section{RESULTS}

The epidemic was in full course at the time the experiment started. Due to administrative difficulties there was delay in making all the necessary arrangements, and then further delay as no snuff could be taken by Muslims during Ramadan. The snuff was given on 24 and 25 March 1961.

The numbers of cases of meningitis reported weekly in each of the six southern districts of the Province for five weeks before and four weeks after administration of snuff in Danja district is shown in Table II. In Galadima, Maska, and Kankara the

\section{TABLE II}

CASES IN SOUTHERN DISTRICTS BEFORE AND AFTER SULPHADIMIDINE SNUFFING IN DANJA DISTRICT

\begin{tabular}{|c|c|c|c|c|c|c|c|c|c|}
\hline \multirow[t]{2}{*}{ District } & \multicolumn{3}{|c|}{ Weeks Before } & \multicolumn{6}{|c|}{ Weeks After } \\
\hline & 5 & 4 & 3 & 2 & 1 & 1 & 2 & 3 & 4 \\
\hline Danja & 38 & 33 & 72 & 68 & 74 & $34^{1}$ & $25^{2}$ & $17^{3}$ & 1 \\
\hline Galadima & 67 & 36 & 64 & 58 & 66 & 96 & 79 & 93 & 38 \\
\hline Maska & 7 & 22 & 17 & 28 & 34 & 39 & 30 & 24 & 20 \\
\hline Musawa & 17 & 20 & 3 & 34 & 28 & 36 & 47 & 18 & 13 \\
\hline Kankara & 36 & 35 & 71 & 22 & 57 & 143 & 70 & 43 & 10 \\
\hline Kogo & 11 & 10 & 24 & 18 & 15 & 6 & 0 & 5 & 4 \\
\hline
\end{tabular}

IIncluding six who had no snuff and 15 strangers who had no snuff. 'Including one who had no snuff and 14 strangers who had no snuff. 'Including 14 strangers who had no snuff.

numbers were rising before, and continued to rise after, 26 March. In Musawa there was a slight drop in the preceding week, followed by a rise after 26 March. In Kogo, a small bush district, the numbers were already falling in the two weeks before 26 March and continued to fall. The epidemic there had already passed the peak.

In Danja district the numbers were rising up to the date of snuffing, and then fell sharply in the following four weeks. As usual, the epidemic died out in all districts with the start of the rains, but the dramatic fall in the Danja district is in sharp contrast to the results in the other districts where no snuff was used. The number of cases dropped from 74 in the previous week to 34 in the following week, and of these 34, six patients were on the lists but had failed to report for snuff, and 15 were untraced and had not been treated. They were probably visitors to the district. The real fall in cases among the population which had received snuff was therefore from 74 to 13 . The following week there were only 10 cases amongst those who had had at least one dose of snuff. In the third week there were only three cases amongst the treated population, and in the fourth week, only one case.

The distribution of cases of meningitis in Danja district according to village areas is shown in Table III. It will be seen that the highest continued
TABLE III

DISTRIBUTION OF CASES IN DANJA DISTRICT BEFORE AND AFTER SULPHADIMIDINE SNUFFING

\begin{tabular}{|c|c|c|c|c|c|c|c|c|c|}
\hline \multirow[t]{2}{*}{ District } & \multicolumn{3}{|c|}{ Weeks Before } & \multirow[b]{2}{*}{2} & \multicolumn{5}{|c|}{ Weeks After } \\
\hline & 5 & 4 & 3 & & 1 & 1 & 2 & 3 & 4 \\
\hline Danja ${ }^{1}$ & 6 & 4 & 7 & 14 & 5 & 4 & 10 & 4 & 1 \\
\hline $\begin{array}{l}\text { Yankwanı } \\
\text { Kabomo }\end{array}$ & & & 2 & 2 & & & & & \\
\hline Kwantakwaram & & & 1 & 4 & & & & & \\
\hline Barde & 2 & 1 & 2 & 2 & 4 & 1 & & 1 & \\
\hline Jiba & & & & & & & & & \\
\hline Guga' & 5 & 8 & 15 & 5 & 6 & 2 & 7 & 3 & \\
\hline Tsiga & & 1 & 4 & 6 & 5 & & & & \\
\hline Yakaji & 6 & 8 & 9 & 4 & 12 & 2 & & & \\
\hline Kakumi ${ }^{1}$ & & & 8 & 8 & 10 & 8 & 3 & & \\
\hline Kahutu & 6 & 4 & 9 & 4 & 10 & 6 & & 1 & \\
\hline D. Musa & & & & 1 & & & & & \\
\hline Tandama & & & & & & & & 1 & \\
\hline Jargaba & & & & & & & & 1 & \\
\hline Tsangamawa & 3 & & 4 & 2 & 2 & & & & \\
\hline Kandarawa & 5 & & & 5 & 4 & 1 & 1 & 4 & \\
\hline $\begin{array}{l}\text { Dabai } \\
\text { Kurami }\end{array}$ & 2 & 4 & 11 & 12 & 9 & 4 & 1 & & \\
\hline Bakori ${ }^{1}$ & 1 & 3 & & 1 & 7 & 6 & 1 & 2 & \\
\hline Totals & 38 & 33 & 72 & 70 & 74 & $34^{3}$ & $25^{4}$ & $17^{5}$ & 1 \\
\hline
\end{tabular}

${ }^{1}$ Market towns on main routes.

${ }^{2}$ Market town not on main routes.

'Includes 21 who had no prophylactic snuff.

'Includes 15 who had no prophylactic snuff.

${ }^{5}$ Includes 14 who had no prophylactic snuff.

incidence of meningitis after snuff was in the villages? of Danja, Guga, Kakumi, and Bakori. These are ale market towns on the main road or routes, wheren the population gathers in large numbers from theo surrounding countryside and from distant villages on market days. Tsiga is another market town, buto well off the main routes, and therefore probably not

\section{TABLE IV}

DISTRIBUTION OF CASES IN GALADIMA DISTRICT BEFORE ANDO AFTER SULPHADIMIDINE SNUFFING IN DANJA DISTRICT

\begin{tabular}{|c|c|c|c|c|c|c|c|c|c|}
\hline \multirow[t]{2}{*}{ District } & \multicolumn{3}{|c|}{ Weeks Before } & \multirow[b]{2}{*}{2} & \multirow[b]{2}{*}{1} & \multicolumn{3}{|c|}{ Weeks After } & \\
\hline & 5 & 4 & 3 & & & 1 & 2 & 3 & \\
\hline Dansarai & & & & & & & 7 & 4 & \\
\hline Yarmama & & & & 1 & & & 1 & & \\
\hline Dantutture & & & & 1 & & & & & \\
\hline Gamzago & & 1 & & 12 & 5 & 21 & 7 & 16 & \\
\hline Malumfashi & 25 & 8 & 11 & 5 & 26 & 9 & 20 & 17 & \\
\hline D. Kura & 9 & 9 & 11 & 1 & 2 & 3 & 5 & 8 & \\
\hline Gozaki & 9 & & & 5 & 1 & 1 & & 1 & \\
\hline Mahuta & 10 & 8 & 10 & 6 & 4 & 7 & & 3 & \\
\hline Masari & 2 & 1 & 1 & 2 & 2 & 2 & 4 & 3 & \\
\hline Kafur & 1 & & & & 1 & 4 & 4 & 9 & \\
\hline Rigoji & 1 & & 3 & & & 2 & 4 & 2 & \\
\hline Yartalata & 3 & & 1 & 5 & & 1 & & & \\
\hline Karfi & 1 & & & & & & & & \\
\hline Yaba & 7 & & 13 & & & 7 & & & \\
\hline S. Kasa & & 2 & & 2 & 3 & 6 & 2 & 9 & \\
\hline Dayi & & 2 & 2 & 1 & 4 & 5 & 7 & 6 & \\
\hline Yaribori & & 2 & 8 & 12 & 18 & 21 & 12 & 11 & \\
\hline Makauraci & & 3 & & 1 & & & & & \\
\hline Dankanjiba & & & 2 & i & & & & & \\
\hline B. Dawa & & & 1 & 3 & & 1 & & & \\
\hline $\begin{array}{l}\text { Na'alma } \\
\text { R. Sanyi }\end{array}$ & & & & & & $\begin{array}{l}4 \\
2\end{array}$ & 6 & 4 & \\
\hline Totals & 68 & 36 & 63 & 58 & 66 & 96 & 79 & 93 & \\
\hline
\end{tabular}


subject to an influx from outside the district. No cases were recorded in Tsiga after snuff. It may be significant that $97 \%$ of the population of Tsiga had received four doses of snuff.

Galadima district, adjacent to Danja district, is comparable to it in size and population. The distribution of cases of meningitis in this district before and after the date of snuffing in Danja district is shown in Table IV. It will be seen that the distribution of cases in village areas is variable, but the total number of cases in Galadima district continued to rise while the numbers in Danja district were falling sharply.

\section{DISCUSSION}

The results achieved in Danja district in the control of epidemic cerebrospinal meningitis show that the method is practicable in an African population which is subject to discipline. It is important that the whole population should be treated at the same time to reduce the number of carriers of the infecting organism. The protection of the community as a whole depends on this factor. The treated carriers will of course be susceptible to reinfection when the effect of the drug wears off, but if the carrier state can be eliminated from a very large majority of the population at one time, the danger of a widespread epidemic will be greatly reduced.
Treatment by snuff produces a high concentration of the sulphonamide in the nasal mucosa which harbours the meningococcus. A satisfactory result could probably be achieved by oral sulphonamides, but the dosage required would be much higher, and would have to be continued over a longer period. The maximum dose of snuff given was $1 \mathrm{~g}$. per dose; $4 \mathrm{~g}$. per person for those who completed the course.

The introduction of prophylactic measures in the middle of an epidemic proved to be very effective, and clearly demonstrated its value. Ideally, prophylactic measures should be introduced to prevent the epidemic, and we strongly recommend that in future such measures should be used on a much broader scale at the beginning of the epidemic season.

The Emir of Katsina and his staff, particularly the Wombai and Alhaji Tsarkin Tsabta, have made the organization of the trial possible.

We are also grateful for assistance given by Dr. Leitch and Dr. Archibald, of the Ministry of Health, Kaduna, Oliver Hunt, Esq., of the Residency, Katsina, and Dr. D. G. Jamison. The Commonwealth Relations Office provided financial assistance.

\section{REFERENCE}

Horn, D. W. (1951). J. roy. sanit. Inst., 71, 573. 